\title{
A Study of SWOT Analysis of Punjab University: Comparison Between Teachers and Students Perceptions
}

\author{
Saghir Ahmad \\ PhD Scholar, Institute of Education and Research, University of the Punjab, Lahore Pakistan \\ Dr. Ayesha Batool \\ Lecturer (Visiting), Institute of Education and Research, University of the Punjab, Lahore Pakistan
}

Prof. Dr. Abid Hussain Ch.

Dean Faculty of Education, Professor, Institute of Education and Research, University of the Punjab, Lahore Pakistan

\begin{abstract}
The purpose of the study was to identify the strengths, weaknesses, opportunities and threats of University of the Punjab, Lahore. In order to develop the rationale of the study, a survey was conducted to comparison the perceptions of respondents in descriptive study. University teachers and students were the population of the study. The sample of the study consisted of 1135 participants (teachers, 235 and students, 900) which were selected through Multistage stratified sampling technique from the University of the Punjab. Data were collected by using adapted questionnaire. Analysis of the data indicated that there was significant difference in the opinions of respondents. Teachers and students had discrimination in their views and this thing was proved by the findings of the study. There was significant difference in their perceptions of teachers and students about university strengths, and opportunities. And there was no significant difference in their perceptions of teachers and students about university weaknesses and threats. There may be conduct environmental analysis before make plans to achieve the desired goals.
\end{abstract}

Keywords: Strengths, weaknesses, opportunities, threats, teachers, students, university.

DOI: $10.7176 /$ RHSS/9-3-03

\section{Introduction}

Higher education is considered backbone for getting success in every field of any society, nation and country. In this quickly changing world it has been a known reality that colleges are being worked in a step by step more lively and unstable worldwide environment which needs very change administration. We are confronting more change as opposed to less, and the pace of progress is going to quicken for both governments and endeavors alike in twenty first century. Specifically, we provoke the contest of changing associations and we should all get to be change operators now (Stace \& Dunphy, 2001).

Emerging nations are left with an impressive undertaking of extending their higher and advanced education frameworks and enhancing worth, absence of environmental analysis and proceeding with economic limitations. Now educational institutions colleges and universities are presently take part in long haul planning, they can productively grow that work by utilizing the ideas of strategic arranging and in this manner improve their capacity to control a course in a dynamic outer surroundings.

Education that is provided in colleges and universities is called higher education. The essential elements of planned organization are to grasp the circumstance through SWOT investigation, describe organizational destinations, recognize options, settle on and execute designs, and evaluate actual implementation. Hence, systematic planning intents to control the creative and particular patterns of future in the wake of examining the foundations inside and remotely, instead of long range planning, which endeavors to improve for tomorrow the plans of today (Drucker, 1980).

SWOT analysis that is utilized for the scanning of institutional environments. It has become a standout element amongst the most mainstream instruments for key planning. SWOT has four factors and stands for Strengths, Weaknesses, Opportunities and Threats. This idea emerged in 1960s (Learned, Christensen, Andrews, \& Guth, 1965), and after that Weihrich spread this unique thought in (1982) with extreme determination. It is commonly used to analyze the situations before taking any decision, it examines the internal and external environment of an institution and promising the improvement of plans which can compete to these circumstances. The use of this analysis has been testified for education institutions and in numerous different fields.

This scrutiny leads you to perceive institution's characteristics and inadequacies, and also more broad opportunities and pressures. Full awareness of the condition helps with both systematic planning and decision making. The SWOT system was at first made and introduced in business organizations, anyway it is excessively useful in crafted by gathering prosperity and change, education, and aside for mindfulness (Hande, 2014).

Systematic planning started from Business School in Harvard since the 1950s. In which the model or idea of 
SWOT investigation introduced for business filed (Delahaye, 2000; Lerner, 1999). The SWOT investigation is to distinguish the different elements deliberately to figure the corporate technique. This analysis relies upon the association and correspondence between inside segments, there are excellence and inadequacy, on the external parts there are better chances and threats (Rangkuti, 2003).

SWOT model is an inspection system and it highlights the qualities, drawbacks, advantages, opportunities and external threats of an institution. It is an approach to seek the outside and inward of showcasing environment (Kotler, 2000; Robbins \& Coulter, 2005). Education, particularly higher education, cannot stand separated from this worldwide marvel. To endure and succeed in this challenging atmosphere, institutional pioneers are requisite to recognize their qualities, decrease their shortcomings, exploit the open doors of opportunities and minimize the impact of coercions. One straightforward, still viable path is to organize a SWOT inspection, a typical part of most vital and strategic plans (Schneider \& Meyer, 1991).

In strategic planning process the SWOT analysis, first there should be conduct analysis of the vision and mission declarations of public and private educational institutions and organizations. And if the institution does not have statement of mission or vision then make or develop these statements before developing the further plan of actions. In exceptionally wide terms, for any institution, general goals or "missions" must be characterized, then inner resources should be surveyed and important parts of outer environment should be evaluated in advance, directing a SWOT analysis and next planning phases (Schraeder, 2002).

There is rapid growing of innovations and change in higher education sectors. Instructive administrators are inciting with changes associated with services, advancing development, developing socioeconomics, growing conflict, expanding costs, and so on. Planning is future confronting and depends on the examination of anticipated or expected patterns and situations. It is adaptable and arranged to convert vision statement into reality (Hinton, 2012; Kotler \& Murphy, 1981; Lerner, 1999; Oztermel, Kubat, \& Taskin, 2009; Paris, 2003; Pisel, 2001, 2008).

In Pakistan to enhance the quality of universities, evaluate the current needs and make plan for the future to compete with progressive countries. Universities require to analyze strengths, and utilize the opportunities properly to speed up with institutes of progressive nations. State administration is busy to overcome the hurdles to make the universities up graded and ensure effectiveness academically. Universities are unable to manage the increasing cost and state is paying concentration on this problem. It is alarming condition for higher education institutions in Pakistan which are lagging behind from the bordering states China, India, Iran and Bangladesh now a days. To adapt to such issues, the general population and private higher institutes need to survey their vital position and make inclusive plans arrangements for the coming days.

Education sector is facing challenges in planning process. Therefore, to achieve a higher institutional performance, emphasis must be given to strategic planning process. There is a solid relation between effectiveness of education and strategic planning process. Effectiveness is emerged in strategic planning when we use SWOT analysis comprehensively in the strategic planning process because it is a main component of strategic planning. To find out the strength, weaknesses, threats and opportunities is the actual work of SWOT analysis in the process of strategic planning (Kotler, 2000).

Systematic planning is vital for educational institutions to manage the market demand and change. It help to accomplish the objectives. It introduces the effective and rapid planning system and organizations make plans by considering strategic factors of planning. This planning method is a point of intermingling for the powerful organization of advanced education associations. Organization surveys of an establishment's characteristics, weaknesses, targets, resource requirements and future estimates in planning, because universities cannot overlook the importance of SWOT model to make a future decisions. It gives the assistance and structure to the directors who need to take right decisions for the improvement of advanced education. The rationale behind the SWOT examination is that the framework an affiliation grasps should organize the natural perils and openings with the affiliation's deficiencies and especially its characteristics. It endeavors to set up a strong association between an institution's inside characteristics and deficiencies, opportunities and risks posed by its external environment. This model of reasoning has by and large been recognized as a prevailing standard of current organization (Beer, Voelpel, Leibold, and Tekie, 2005). Those organizations or institutions, which do not give importance to SWOT analysis in strategic planning process, may make poor decisions, which may lead to costly and time consuming to perform functions efficiently and effectively to achieve their goals. Therefore, this study was planned to vet the SWOT Analysis of University of the Punjab Lahore.

\section{Significance of Study}

This study has significant importance with respect to the various reasons. This study helps the higher education, in targeting the issues regarding the institutional environments in public sectors. This study highlights the strengths, weaknesses, opportunities and threats of Punjab University. This study guides about the importance of SWOT analysis of the higher educational institution to improve the management abilities for strategic planning process. The results of the study may provide valuable information for the design of SWOT analysis preparation for the betterment of the strategic planning. It also encourages the state educational policy makers to strengthen the 
strategic planning process related to system of education. The study may help to make the strong communication way for future planning. The study helps to promote the SWOT analysis in education sectors. It is anticipated that the consequence of the study may be useful for higher education system in decision making about need based planning.

\section{Research Objectives}

The study was conducted to achieve the following objectives to:

1. Identify the strengths, weaknesses, opportunities, and threats of Punjab University.

2. Examine the difference in teachers and students perceptions regarding strengths, weaknesses, opportunities, and threats of Punjab University Lahore.

\section{Research Methodology}

This section of the study deals with description of procedure that the researchers followed to conduct this study. Quantitative approach was employed for conducting the study. The study was descriptive and survey type in nature. The population of the study was consisted of teachers and students from University of the Punjab Lahore. Multistage stratified random sampling technique was used to draw sample. At the first stage, 13 faculties were selected as strata. At the second stage, three departments randomly selected from each faculty. At the third stage, 75 students (Twenty five students from each department) and 20 teachers were taken randomly as a sample from each faculty. In this way, total sample was depended on teachers and students respectively of University of the Punjab.

Questionnaire is a vital and well established research tool in social sciences research for acquiring information on participants' characteristics, knowledge, thoughts, experiences and their behavior (Bulmer, 2004). Falk (2011) developed a scale in this context and this questionnaire was adapted with the consent of author. Data were collected by using likert-type questionnaire. Reliability of the questionnaire was ensured to check the internal consistency of the items.

\section{Data Analysis}

A detail description of data analysis is as under.

Table 1

Reliability Index of SWOT Analysis

\begin{tabular}{ccc}
\hline Instrument & Cronbach's Alpha & No. of Items \\
\hline SWOT Analysis & 0.87 & 66 \\
\hline
\end{tabular}

Table shows the reliability index of the SWOT analysis. There were 66 statements in this instrument. The value of Cronbach's alpha was 0.87 , which is statistically significant.

Researchers visited different departments for data collection. Consent was taken from teachers and students and then circulated the questionnaire for getting required data. They were provided clear guidelines and directions related questionnaire. Data were analyzed by applying descriptive (frequency, mean, standard deviation) and inferential (independent sample t-test) statistical techniques.

Table 2

Frequencies and percentages of Selected Teachers $(N=235)$.

\begin{tabular}{lcc}
\hline Teacher Ranks & $\boldsymbol{N}$ & $\mathbf{( \% )}$ \\
\hline Lecturer & 82 & 35 \\
Assistant Professor & 75 & 32 \\
Associate Professor & 43 & 18 \\
Professor & 35 & 15 \\
\hline
\end{tabular}

Table indicates the ranks of teacher and percentage of selected teachers. The first part of study based on teachers' perceptions of Punjab University. It was showed that majority 82 teachers had lecturer rank. Second 75 teachers had rank of assistant professor in selected sample. 43 teachers had rank of associate professor and few teachers professor and that were 35 in their numbers.

Table 3

\begin{tabular}{lcc}
\hline Student Programs & $\boldsymbol{N}$ & $\mathbf{( \% )}$ \\
\hline BS Honor & 392 & 43 \\
M.A, MSC & 355 & 40 \\
M.phil & 141 & 15 \\
Ph.D & 12 & 2 \\
\hline
\end{tabular}

Frequencies and percentages of Selected Students $(N=900)$.

Table indicates the ranks of students and percentage of selected students. The second part of study was based on students' perceptions of Punjab University. It was showed that majority 392 students had BS Honor rank. Second 355 students had rank of M.A, MSC in selected sample. 141 students had rank of M.phil and few students 
of Ph.D and that were 12 in their numbers.

Table 4

Mean and Standard Deviations of Teachers and Students Responses about University Strengths

\begin{tabular}{lcccc}
\hline University has following strengths & \multicolumn{2}{c}{ Teachers } & \multicolumn{2}{c}{ Students } \\
\cline { 2 - 5 } & $M$ & $S D$ & $M$ & $S D$ \\
\hline Provides curricular and co-curricular activities & 4.38 & .905 & 3.77 & 1.205 \\
Civic engagement knowledge & 3.89 & .894 & 3.55 & .985 \\
Opportunities to study abroad & 3.79 & .903 & 3.24 & 1.210 \\
Research oriented environment & 4.03 & .816 & 3.57 & 1.129 \\
Recreational activities & 3.95 & .912 & 3.48 & 1.118 \\
Accredited Programs & 4.27 & .858 & 3.65 & 1.024 \\
Friendly and safe environment & 4.26 & .933 & 3.67 & 1.180 \\
Impact on educational, economical, and cultural aspects & 3.94 & .833 & 3.76 & .923 \\
Attractive buildings and grounds & 3.97 & .942 & 3.74 & 1.042 \\
Enrollment in undergraduate and graduate programs & 4.47 & .741 & 3.86 & .943 \\
Effective and supportive teaching and learning environment & 4.26 & .683 & 4.05 & .932 \\
Workforce is stable and talented & 4.07 & .759 & 3.75 & .906 \\
Positive reputation & 4.05 & .780 & 3.90 & .935 \\
Diversity of disciplines & 4.13 & .845 & 3.71 & 1.006 \\
Interaction between faculty and students & 4.12 & .794 & 3.60 & 1.082 \\
Strong sense of community & 4.11 & .777 & 3.65 & 1.026 \\
Provoking loyalty to institution & 4.06 & .838 & 3.61 & 1.021 \\
Economically sound and well managed institution & 4.16 & .825 & 3.73 & 1.084 \\
\hline
\end{tabular}

Table shows teachers and students opinions about strengths of Punjab University Lahore. A sample of selected teachers of all faculties were strongly agree about strengths of Punjab University. The second part of the sample was students and majority of them agreed but not strongly agreed about strengths of Punjab University. A very few students had their perceptions neutral about the Punjab university' strengths.

Table 5

Mean and Standard Deviations of Teachers and Students Responses about University Weaknesses

\begin{tabular}{|c|c|c|c|c|}
\hline \multirow[t]{2}{*}{ University has following weaknesses } & \multicolumn{2}{|c|}{ Teachers } & \multicolumn{2}{|c|}{ Students } \\
\hline & $M$ & $S D$ & $M$ & $S D$ \\
\hline Lacks of good governance, check and balance & 2.42 & 1.319 & 3.02 & 1.341 \\
\hline Most students have limited time for study & 3.06 & 1.188 & 3.40 & 1.060 \\
\hline Inconsistent academic structure and outdated curriculum & 2.30 & 1.214 & 2.98 & 1.180 \\
\hline Dispersal of information needs to be streamlined & 3.29 & 1.002 & 3.52 & 1.012 \\
\hline Lacks sufficient financial support & 2.87 & 1.076 & 3.39 & 1.145 \\
\hline Higher tuition fee & 2.12 & 1.137 & 2.77 & 1.345 \\
\hline Faculty limited commitments & 3.32 & 1.037 & 3.37 & 1.019 \\
\hline Time demands on faculty professional development & 3.29 & 1.025 & 3.46 & 1.004 \\
\hline Services are not adequate & 2.69 & 1.001 & 3.23 & 1.094 \\
\hline Inadequate resources for recruitment & 2.97 & 1.097 & 3.17 & 1.106 \\
\hline Involvement of politics & 3.97 & .942 & 3.51 & 1.193 \\
\hline Lacks a strong mission, vision, and identity & 2.12 & 1.210 & 2.86 & 1.357 \\
\hline Failing in judgment of market needs & 2.31 & 1.155 & 2.95 & 1.152 \\
\hline Directionless research development & 2.27 & 1.196 & 2.95 & 1.180 \\
\hline Misuse of funds and facilities & 2.64 & 1.128 & 3.06 & 1.157 \\
\hline Implementation of plans & 3.04 & 1.139 & 3.17 & 1.265 \\
\hline
\end{tabular}

Above table demonstrates the teachers and students opinions about weaknesses of Punjab University Lahore. Majority of the teachers of all faculties were not agree about weaknesses of Punjab University. According to them there dispersal of information needs to be streamlined, faculty members may show their commitments with task and duties, and should avoid from politics.

It also shows that students of all faculties had variation among their opinions due to which they have different perceptions from their teachers about weaknesses of Punjab University. They think university is going towards weaknesses and there are various factors behind this aspect. There is lack of financial support due to this services provided by university are not enough. One of the main problem is politics and this contagious disease is increasing day by day in university teachers and students. 
Table 6

Mean and Standard Deviations of Teachers and Students Responses about University Opportunities

\begin{tabular}{lcccc}
\hline University has following opportunities & \multicolumn{2}{c}{ Teachers } & \multicolumn{2}{c}{ Students } \\
\cline { 2 - 5 } Natural environment & $M$ & $S D$ & $M$ & $S D$ \\
Partnerships with local employers & 4.33 & .692 & 4.06 & .916 \\
Location & 4.07 & .709 & 3.70 & .856 \\
Advantage of location & 4.14 & .678 & 3.85 & .911 \\
Focus on excellence & 4.09 & .743 & 3.78 & .998 \\
Experience using the best practices & 4.00 & .768 & 3.80 & .969 \\
Collaborative approaches & 4.02 & .855 & 3.69 & 1.011 \\
Multimedia technology & 3.97 & .816 & 3.70 & .947 \\
Multimedia affects teaching and learning. & 4.29 & .796 & 3.84 & 1.019 \\
Technology meets educational needs of students. & 4.26 & .821 & 3.80 & 1.019 \\
Increase student enrollments & 4.11 & .791 & 3.77 & .999 \\
Interdisciplinary and integrated learning. & 3.95 & .836 & 3.72 & .994 \\
Solving crisis and disasters. & 3.90 & .898 & 3.59 & .973 \\
Systematic performance assessment & 3.88 & .890 & 3.56 & 1.103 \\
Raising admission standards & 4.39 & .647 & 4.07 & .848 \\
Enrollment of international students. & 3.86 & 1.002 & 3.79 & .930 \\
\hline \multicolumn{1}{l}{ Table highighyyyyyyy}
\end{tabular}

Table highlights the teachers and students views about opportunities which university has. Mostly teachers and students agreed that university has natural environment, takes advantage of its location, focuses on excellence, introduced multimedia technology to compete in the academic field and assesses the students' performance in systematic way. International students of different countries are showing interest of enrollment in Punjab University. Due to these above mentioned opportunities university is enjoying its status in the country as well as worldwide.

Table 7

Mean and Standard Deviations of Teachers and Students Responses about University Threats

\begin{tabular}{lcccc}
\hline University has following threats & \multicolumn{2}{c}{ Teachers } & \multicolumn{2}{c}{ Students } \\
\cline { 2 - 4 } & $M$ & $S D$ & $M$ & $S D$ \\
\hline Increasing tuition fee & 4.01 & 1.052 & 3.77 & 1.023 \\
Declining financial support & 3.86 & .902 & 3.65 & .956 \\
K-12 students less prepared for university education & 3.76 & 1.028 & 3.55 & 1.028 \\
Rapidly changing educational environment & 3.98 & .882 & 3.67 & 1.055 \\
New programs & 3.69 & .989 & 3.61 & 1.028 \\
Growth of corruption and unfairly mandates & 3.00 & 1.177 & 3.41 & 1.058 \\
Loss of public support & 2.53 & 1.224 & 3.21 & 1.202 \\
Decreasing ability to compete and retain top faculty & 2.54 & 1.272 & 3.17 & 1.197 \\
On-line academic system & 3.60 & 1.030 & 3.65 & 1.029 \\
Declining number of college graduate students & 3.05 & 1.116 & 3.25 & 1.140 \\
Politics & 3.61 & .920 & 3.49 & 1.120 \\
Incompetent and outdated management & 2.31 & 1.257 & 3.05 & 1.236 \\
Rapid expansion of private universities & 3.52 & 1.043 & 3.59 & 1.095 \\
Brain Drain & 3.41 & 1.138 & 3.45 & 1.113 \\
HEC Body is losing its recognition. & 2.66 & 1.149 & 3.05 & 1.227 \\
Less pay & 2.74 & 1.163 & 2.96 & 1.318 \\
\hline
\end{tabular}

Table shows the teachers and students opinions about threats which may harmful for university. There are different views of teachers and learners about threats. Teachers said university is not losing public support but students' perceptions are vice versa. Teachers argued university has ability to compete and retain top position in ranking. They admitted that university has competent and updated management. There is no concept and threat of less pay of university. 
Table 8

An Independent Sample t-test for Difference in Perceptions of Teachers and Students about Strengths, Weaknesses, Opportunities and Threats of University

\begin{tabular}{lccccccc}
\hline Factors & Respondent & $\boldsymbol{N}$ & $\boldsymbol{M}$ & $\boldsymbol{S D}$ & $\boldsymbol{t}$-value & $\boldsymbol{d f}$ & Sig. \\
\hline Strengths & Teachers & 235 & 4.1069 & .46217 & 11.748 & 457.064 & .000 \\
Weaknesses & Students & 900 & 3.6831 & .59377 & & & .290 \\
\multirow{3}{*}{ Opportunities } & Teachers & 235 & 2.7920 & .61237 & -8.517 & 1133 & \\
& Students & 900 & 3.1767 & .61754 & & & .000 \\
Threats & Teachers & 235 & 4.0795 & .40316 & 9.558 & 447.143 & \\
& Students & 900 & 3.7808 & .50681 & & & .256 \\
& Teachers & 235 & 3.2668 & .53696 & -3.490 & 1133 & \\
\hline
\end{tabular}

Independent sample t-test was applied to compare the Strengths scores for teachers and students. There was significant difference in scores between teachers $(M=4.1069, \mathrm{SD}=.46217)$ and students, $\mathrm{M}=3.6831$, $\mathrm{SD}$ $=.59377 ; \mathrm{t}(11.748)=457.064, \mathrm{p}=.000$. There was no significant difference regarding university weaknesses in scores between teachers $(\mathrm{M}=2.7920, \mathrm{SD}=.61237)$ and students, $\mathrm{M}=3.1767, \mathrm{SD}=.61754 ; \mathrm{t}(-8.517)=1133, \mathrm{p}$ $=.290$. There was significant difference regarding university opportunities between teachers $(\mathrm{M}=4.0795, \mathrm{SD}$ $=.40316)$ and students perceptions, $\mathrm{M}=3.7808, \mathrm{SD}=.50681 ; \mathrm{t}(9.558)=447.143, \mathrm{p}=.000$. There was no significant difference regarding university threats between teachers $(\mathrm{M}=3.2668, \mathrm{SD}=.53696)$ and students perceptions, $\mathrm{M}=3.4078, \mathrm{SD}=.55564 ; \mathrm{t}(-3.490)=1133, \mathrm{p}=.256$.

It is concluded that there was significant difference in their perception scores between teachers and students of university regarding the institutional environment strengths, and opportunities. And there was no significant difference in their perception scores between teachers and students of university regarding the institutional environment weaknesses, and threats.

\section{Conclusion}

The present study was conducted to have a clear picture of the SWOT analysis regarding the institutional environments of university. The sample of the study was teachers and students of University of the Punjab Lahore. It is concluded that teachers were strongly agree about strengths of Punjab University. The second part of the sample was students and majority of them agreed but not strongly agreed about strengths of university. Teachers and students said dispersal of information needs to be streamlined, faculty members may show their commitments with task and duties, and should avoid from politics. Students claimed there is lack of financial support and services are not enough. Politics is contagious disease and increasing day by day in university teachers and students. Both teachers and students accepted that university has natural environment, takes advantage of its location, focuses on excellence, and introduced multimedia technology for teaching and learning. International students are willing to be a part of Punjab University. It is concluded that there was significant difference in their perceptions between teachers and students about strengths, and opportunities of university. But there was no significant difference in perceptions of teachers and students about institutional weaknesses and threats.

SWOT analysis is an essential component of strategic planning procedure to help associations to comprehend their qualities or strengths, shortcomings or weaknesses, opportunities and threats. The SWOT analysis can be basic element to the particular institutional circumstances. For Punjab University, to face numerous difficulties postured by the globalization and the new market-driven economy, the university needs to create strategic planning approach, and SWOT ought to be the first precise endeavor to develop strategic planning. It is confirmed that the universities of twenty first century will succeed unless they can react to social needs with rate, proficiency, viability and quality (Navarro \& Gallardo, 2003). In the education field it is compulsory to executives and plan makers to think and make plans strategically. In the setting of the quickly evolving world, this will be an essential for any institutional survival and flourishing.

Note that the data from the SWOT analysis of Punjab University does not mean just to make a list of strengths, weaknesses, opportunities and threats. The university's planning board of trustees need to coordinate inside elements with outside elements to highlight conceivable regions for institutional achievements. For instance, when organization strengths are associated with opportunities of the environment, they demonstrate the institutional influence, positional benefit for the institution to succeed. In the meantime, notable weaknesses must be evaluated in more detail to characterize fundamental steady action. "Know your opponent, and know yourself, you can battle a hundred fights without fear of defeat" because it is necessary to compete the situations. Due to which SWOT has comprehension importance in this regard.

\section{Recommendations}

Following are the recommendations for future:

1. There may be conduct environmental analysis before make plans to achieve the desired goals. 
2. It is suggested that there may be special department or system of assessment in each university especially in Punjab University which plays its role to organize, assess and evaluate the institutional environments.

3. Further research can be conducted on comparison of private and government sector institutions of higher education.

4. This study was conducted at Punjab University Lahore, it also can be conducted at college or school level.

5. This study consisted of teachers and students of the university, other persons like staff employees, alumni, can be included in further studies.

\section{References}

Beer, M., Voelpel, S. C., Leibold, M., \& Tekie, E. B. (2005). Strategic management as organizational learning: Developing fit and alignment through a disciplined process, Long Range Planning, 38, 445-465.

Bulmer, M. (2004). Questionnaires, SAGE benchmarks in social research methods. (1st ed.). London: SAGE Publications Ltd.

Delahaye, B. L. (2000). Strategic human resource development. Milton: John Wiley \& Sons.

Drucker, P. (1980). Managing in turbulent times. New York: Harper \& Row.

Falk, D. (2011). Strengths, weaknesses, opportunities, and threats; Draft, UMD SWOT Preliminary Results.

Hande, S. (2014). Strengths weaknesses opportunities and threats of blended learning: Students' perceptions. Ann Med Health Science Res, 4(3), 336-339.

Hinton, K. E. (2012). A practical guide to strategic planning in higher education. Society for College and University Planning.

Kotler, P., \& Murphy, P. E. (1981). Strategic planning for higher education. The Journal of Higher Education, $52(5), 470-489$.

Kolter, P. (1988). Marketing management: Analysis, planning, implementation, and control (6th ed.). PrenticeHall International Edition.

Kotler, P. (2000). Marketing management. Upper Saddle River, NJ: Prentice-Hall.

Learned, E. P., Christensen, C. R., Andrews, K. E., \& Guth, W. D. (1965). Business policy: Text and cases. Irwin, Homewood, IL.

Lerner, A. L. (1999). A strategic planning primer for higher education, College of Business Administration and Economics, California State University, Northridge. Retrieved from http://grapevine.laspositascollege.edu/academicservices/documents/InstitutionalEffectiveness/CSUStrategic PlanningReport.pdf.

Navarro, J. R., \& Gallardo, F. O. (2003). A model of strategic change: Universities and dynamic capabilities. Higher Education Policy, 16(1), 199-212.

Oztemel, E., Kubat, C., \& Taskin, H. (2009). A road map for strategic planning in higher education institutions. 6th Research/Expert Conference with International Participations “QUALITY 2009”, (601-610), Neum.

Panagiotou, G. (2003). Bringing SWOT into focus. Business Strategy Review, 14(2), 8-10.

Paris, K. A. (2003). Strategic planning in the university. University of Wisconsin System Board of Regents.

Piorun, M. (2011). Evaluation of strategic plans in academic medical libraries, Library \& Information Science Research, 33, 54-62.

Pisel, K. P. (2001). The validation of a detailed strategic planning process model for the implementation of distance education in higher education. Norfolk, VA: Old Dominion University.

Pisel, K. P. (2008). A strategic planning process model for distance education. Online Journal of Distance Learning Administration, 9(2). Retrieved from http://www.westga.edu/ distance/ojdla/summer112/pisel112.html.

Rangkuti, F. (2003). Analysis SWOT teknik membedah kasus bisnis. Jakarta. Gramedia Pustaka Utama

Robinson, R. (2003). How to conduct a SWOT analysis: ABARIS Consulting Inc. Retrieved 8 July 2006 from http://www.charityvillage.com/cv/research/rstrat19.html.

Robbins, S. P., Coulter, M. (2005). Management (11th ed.). Pearson Education, Inc., Prentice Hall, One Lake Street, Upper Saddle River, New Jersey 07458.

Schneider, S. C., \& Meyer, D. A. (1991). Interpreting and responding to strategic issues:

The impact of national culture. Strategic Management Journal, 12(1), 307-320.

Schraeder, M. (2002). A simplified approach to strategic planning: Practical considerations and an illustrated example. Business Process Management, 8(1), 818.

Stace, D., \& Dunphy, D. C. (2001). Beyond the boundaries: Leading and re-creating the successful enterprise (2nd ed.). McGraw Hills: Sydney.

Uvalic-Trumbic, S. (2003). Higher education in a globalized society: UNESCO education position paper. Retrieved 25 July 2006 from http://www.unesco.org/iau/pdf/unesco position_paper_globalization_he.pdf.

Weihrich, H. (1982). The TOWS matrix: A tool for situational analysis, Long Range Planning, 15(2), 54-66. 